\title{
Walking and walkability: do built environment measures correspond with pedestrian activity?
}

\author{
Caminhadas e caminhabilidade: como métricas do \\ ambiente construído e as atividades de pedestres estão \\ relacionadas?
}

\section{Mateus Humberto \\ Rodrigo Laboissière \\ Mariana Giannotti \\ Cláudio Luiz Marte \\ Daniel Agostini Cruz Henrique Primon}

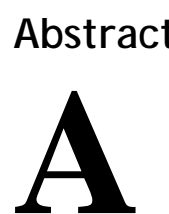

fter the emergence of the term "walkability" in the 1990's, many metrics have been developed with the aim of evaluating the quality of the built environment for pedestrians. More recently, researchers have also sought an association of these metrics with pedestrian behavior: do better sidewalk conditions and their surroundings correspond with higher pedestrian activity? To study the association of the built environment with the share of pedestrian movements, two different indexes, one at the city level (macro) and one at the neighborhood level (micro), were proposed using georeferenced data from São Paulo (Brazil). Once the available built environment and transportrelated data were incorporated in a linear regression model, the neighborhood-level index (micro) and the share of pedestrian movements presented a strong positive correlation (adjusted $\mathrm{R}^{2}=0.797$ ). In addition to the contributions to the relationship of walkability scores with data from developing countries, the

1 Mateus Humberto

${ }^{1}$ Universidade de Lisboa Lisboa - Portuga http:// orcid. org/0000-0002-6602-5708

${ }^{2}$ Rodrigo Laboissière ${ }^{2}$ Universidade de São Paulo São Paulo - SP - Brasil

${ }^{3}$ Mariana Giannotti ${ }^{3}$ Universidade de São Paulo São Paulo - SP - Brasil

${ }^{4}$ Cláudio Luiz Marte ${ }^{4}$ Universidade de São Paulo São Paulo - SP - Brasil

${ }^{5}$ Daniel Agostini Cruz 5Universidade de São Paulo São Paulo - SP - Brasil

${ }^{6}$ Henrique Primon 6Universidade de São Paulo São Paulo - SP - Brasil

Recebido em 28/05/18 Aceito em 04/11/18 discussions presented in this paper intend to provide insights into the territorial disparities in pedestrian mobility, mainly those related to socio-spatial segregation.

Keywords: Urban mobility. Built environment. Active travel. Walkability.

\section{Resumo}

Desde o surgimento do termo “caminhabilidade”, na década de 1990, muitas métricas foram desenvolvidas com o intuito de avaliar a qualidade do ambiente construído sob a ótica do pedestre. Mais recentemente, alguns pesquisadores têm buscado uma associação dessas métricas com o comportamento dos pedestres: melhores condições das calçadas e de seus entornos estão alinhadas com mais atividades de pedestres? A fim de investigar a relação do ambiente construído existente com a proporção de deslocamentos a pé, um indicador no nível da cidade (macro) e outro no nível do bairro (micro) foram desenvolvidos a partir de dados georreferenciados da cidade de São Paulo. Uma vez que os dados disponíveis sobre o transporte e o ambiente construído foram incorporados em um modelo de regressão linear, o o índice na escala do bairro (micro) e a proporção de deslocamentos a pé apresentaram uma forte correlação positiva $\left(R^{2}\right.$ ajustado $\left.=0,797\right)$. Além da contribuição acerca da relação de métricas de caminhabilidade com dados de países em desenvolvimento, as discussões apresentadas neste artigo pretendem fornecer subsídios para a avaliação de desigualdades territoriais na mobilidade a pé, em especial as relacionadas à segregação socio-espacial.

Palavras-chave: Mobilidade urbana. Ambiente Construído. Transporte ativo. Caminhabilidade. 


\section{Introduction}

An integrated consideration of both natural and built environments in transportation planning brings attention to the importance of data and its outcomes in identifying, discussing, and anticipating problems not only among scholars and municipalities but also for non-governmental organizations (NGO) and other civil organizations. Due mainly to the absence of accessible datasets, the diagnosis and implementation of the most fundamental parts of the planning process lack methods regarding the analysis of pedestrians and other active modes. Large cities amplify this shortage since the scale of pedestrians requires a degree of detail that hampers the analysis by public managers.

The incorporation of the characteristics of pedestrian movements can be grouped into two main approaches. In project-oriented studies, at smaller scales and with a more refined level of analysis, the attributes are normally summarized according to concepts from traffic engineering, such as the associated level of service (LOS) for pedestrian flows (GONÇALVES, 1978; NZ..., 2009). For more aggregated data regarding largescale patterns of pedestrian movements, however, some studies tend to comprise sets of indicators that are more related to physical conditions, such as the road network and land use. The latter, which is the focus in this paper, is referred to as the walkability (of a neighborhood, district, or city), term that emerged in the 1990s (BRADSHAW, 1993) and has been used by different metrics with the aim of evaluating the quality of the built environment for pedestrians. The sets of indicators present a diversity of factors, different levels of analysis, and several contexts and approaches towards performing studies on active mobility.

Through walkability metrics, some authors have sought to identify areas with high potentials for walking (ACKERSON, 2005; RODRIGUES et al., 2014; TALEN; KOSCHINSKY, 2013), while others have focused on access to public transportation (PAIXÃO; DELGADO, 2014; PASSMORE, 2007) and on the association with socioeconomic elements and the built environment (AMANCIO, 2005; CERVERO et al., 2009; CERVERO; KOCKELMAN, 1997). These metrics have been developed with the aim of better designing diagnoses regarding the conditions for pedestrians (GRIECO; PORTUGAL; ALVES, 2016).

More recently, researchers have sought an association of these metrics with pedestrian behavior, i.e., whether better sidewalk conditions and their surroundings correspond with higher pedestrian activity. Apart from some recent contributions (CRANEA; CREPEAUB, 1998; KRIZEK; HANDY; FORSYTH, 2009; VALE; PEREIRA, 2016), there is not a consolidated view on the relationship between built environment measures and the walking characteristics in the field. In addition, studies are lacking that assess the walking conditions of pedestrians in developing countries, which is a focus of this study.

Through the development of an Attractiveness Index (AI) for pedestrian movements for the city of São Paulo (Brazil), some discussions regarding the association of walking and walkability are proposed:

(a) the diversity of relationships according to the neighborhood and region within a city; and

(b) the importance of Origin-Destination (OD) surveys to support the comparison between waking and walkability indexes, through the correlation analysis between attractiveness of the built environment and the pedestrian movements.

To do this, this paper is structured as follows: first, a data description is provided with the scale of analysis, and methods adopted to develop the index at both the city and neighborhood levels. Second, the results of the AI and its relationships with pedestrian movement data (OD survey) are presented, and the verification and the validity of the adopted regression model are evaluated followed by a critical discussion. Finally, the conclusion includes suggestions, limitations, and possible considerations for future research. In addition to highlighting the importance of discussing the urban mobility of cities in developing countries, the proposed approach is also adaptable to diverse environments and could be tested in other cities.

\section{Methodology \\ Pedestrian trips to pedestrian movements}

The analysis of pedestrian movements through OD surveys involves many issues since most of the surveys are oriented towards public transportation agencies and usually only include movements more than 15 minutes or 5 blocks long. This approach eliminates short trips and reduces the number of actual movements assigned to pedestrians (VASCONCELLOS; MENDONÇA, 2017). The consideration of an alternative concept (pedestrian movements) rather than the trips typically considered in transport planning was required since 
the conceptualization via transport planning traditionally undermines considerations of short trips as trips per se, especially in active modes such as walking and cycling (VASCONCELLOS, 2017). In São Paulo’s OD survey, a pedestrian trip is only incorporated if it covers more than five blocks (approximately 500 meters) and is performed as a single mode, i.e., it is not quantified when it is combined with other transportation modes (METRÔ, 2013). To allow for an estimation of the actual number of pedestrian movements (instead of pedestrian trips considered by the OD survey) both the origin and destination of public transportation trips were used to include two new pedestrian movements. This methodology was proposed in 2015 by the Brazilian National Association of Public Transportation (ASSOCIAÇÃO..., 2015), as shown in Figure 1.

Alongside the pedestrian trips provided by the most recent OD survey in Metropolitan São Paulo (METRÔ, 2008), the adopted procedures generated a new set of pedestrian movements within the zones previously delimited in the survey. The increased number of movements is in line with other studies on this topic (VASCONCELLOS, 2017).

The geographic delineation of the transportation survey, composed of OD zones, constitutes the territorial unit used by the São Paulo Subway System (METRÔ-SP) to ensure the statistical validity of the collected data. In addition to presenting an intermediate scale between the census tract and the district level, the OD zone's unit area makes it possible to aggregate periodic socioeconomic and transport-related data from both the Census and the OD survey itself. Moreover, the limits of OD zones allow for important analyses, such as road network connectivity and the density of transit stops in an aggregated level, which cannot be considered in the census tract level. By considering the transit system dynamics, the OD zone enables a more consistent analysis of mobilityrelated issues, such as the walkability and AI discussed in this paper.

\section{City-level pedestrian Attractiveness Index (Al-macro) and Comparison Index (CI)}

To develop a pedestrian AI at the city level (AImacro) capable of representing how a specific zone performs in terms of pedestrian facilities (natural environment, urban infrastructure, and public services), secondary georeferenced data were sought together with public agencies, research centers, universities, and civil society associations in São Paulo, Brazil. This approach allowed for the construction of 19 indicators of pedestrian attractiveness in 320 different zones, constituting five categories: integrity of road network, diversity of land use, education, road safety, and access to public transportation. The development of the AImacro index was based on indicators that seek to develop pedestrian-tailored metrics (FITZPATRICK et al., 2006; KRIZEK, 2003; MAGHELAL; CAPP, 2011; MICHAEL; GREEN; FARQUHAR, 2011; PARTHASARATHI; LEVINSON; HOCHMAIR, 2013), which nevertheless lack representation in pedestrian issues in developing countries. Besides considering the variables that seem relevant for the appraisal of pedestrian mobility in cities in developing countries, the availability of datasets at the city level was also fundamental for the development of the AI-macro. The covered categories and the indicators that compose them are represented in Table 1.

The categories and respective indicators therefore represent metrics that are expected to contribute positively to the attractiveness of pedestrian movements in each OD zone. The majority of pedestrian trips were motivated by education (55\% of trips, not only by children or at the school level), which determined that related indicators would be considered in a separate category of attractiveness (CRUZ et al., 2015; METRÔ, 2008).

To elaborate a single attractiveness metric from the built indicators, the Analytic Hierarchy Process (AHP) was adopted as a multicriteria aggregation method (LEE; CHAN, 2008). To do this, pairwise comparisons between the indicators of each category were performed by the participating team of researchers, followed by comparisons among the categories that yielded a Consistency Ratio (CR) of $11.1 \%$. Values of CR below $10 \%$ are typically considered acceptable, and ranges between 10\% and $20 \%$ are considered moderately acceptable (SAATY, 1990; WEDLEY, 1993). The aggregated attractiveness score, the so-called pedestrian AI at the city level (AI-macro), was obtained through a weighted average additive aggregation model and indicates how appealing each OD zone is in light of the evaluated characteristics of the built environment at the city level. The comparison matrix and respective weights are indicated in Table 2. 
Figure 1 - Comparison between the total estimated number of trips (on the left) and the total number of movements (right) in Brazilian cities by transport mode

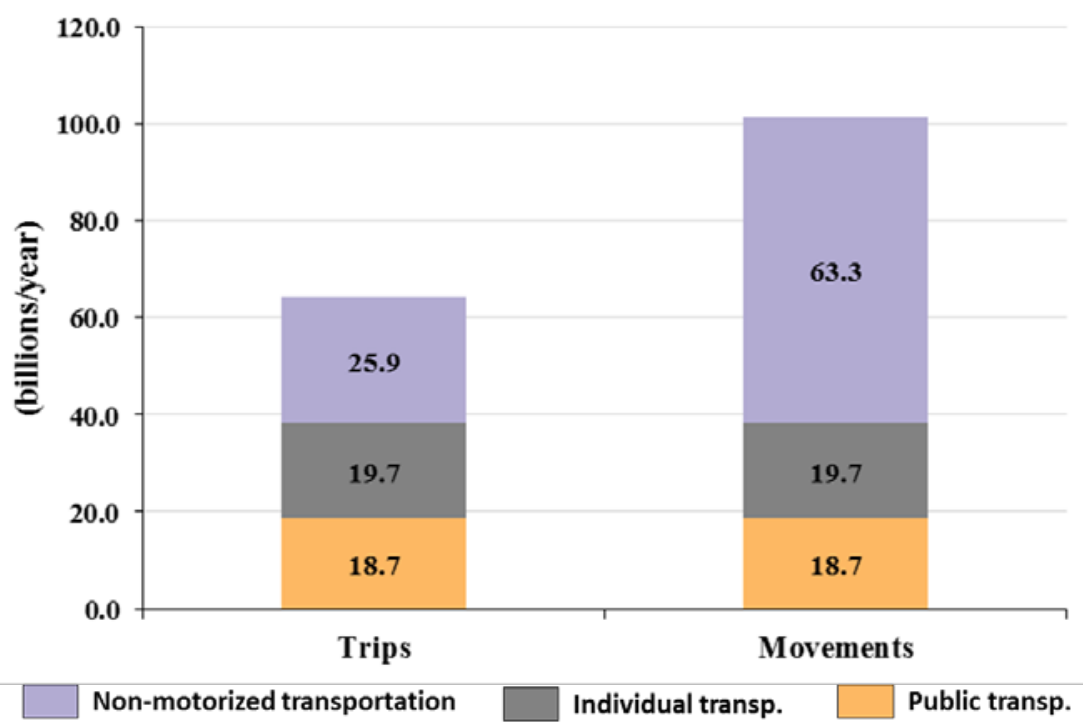

Note: extracted from ANTP (2015: 8).

Table 1 - Five categories and their nineteen indicators that guided the development of the Al-macro. Distribution of indicator values in quartiles ( $1^{\text {st }}$ quartile / median / $3^{\text {rd }}$ quartile) and average value (in brackets) among OD zones of São Paulo ( $N=320)$

\begin{tabular}{|c|c|c|}
\hline Category & Indicator [unit] & $\begin{array}{c}\text { Distribution } \\
\text { Quartiles (average) }\end{array}$ \\
\hline $\begin{array}{l}\text { Integrity of } \\
\text { road network }\end{array}$ & $\begin{array}{l}\text { Average slope of streets [\%] } \\
\text { Density of street length [km] } \\
\text { Intersection density by street length }[\mathrm{n} / \mathrm{km}] \\
\text { Intersection density by urban area [n/km2] }\end{array}$ & $\begin{array}{l}4.4 \text { / } 7.9 \text { / } 9.8(7.3) \\
20 / 41 \text { / } 66(48) \\
7.2 \text { / } 8.2 \text { / } 9.3(8.2) \\
128 / 154 \text { / } 185(161)\end{array}$ \\
\hline $\begin{array}{l}\text { Diversity of } \\
\text { land use }\end{array}$ & $\begin{array}{l}\text { Entropy index [dimensionless] } \\
\text { Share of built area for collective use [\%] } \\
\text { Share of built area for residential use [\%] } \\
\text { Share of built area non-residential use [\%] }\end{array}$ & $\begin{array}{l}0.6 / 0.67 / 0.72(0.65) \\
17 / 22 / 30(26) \\
53 / 70 / 77(62) \\
23 / 30 / 47(38)\end{array}$ \\
\hline Education & $\begin{array}{l}\text { No. of children enrolled per urban area [n/ha] } \\
\text { No. of youngsters enrolled per urb. area [n/ha] } \\
\text { No. of adults enrolled per urban area [n/ha] }\end{array}$ & $\begin{array}{l}346 \text { / } 565 \text { / } 828 \text { (634) } \\
1166 \text { / } 2020 \text { / } 3142(2245) \\
107 \text { / } 385 \text { / } 747 \text { (537) }\end{array}$ \\
\hline Road safety & $\begin{array}{l}\text { Traffic crashes per street length [n/1000 km] } \\
\text { Traffic crashes per urban area [n/km2] }\end{array}$ & $\begin{array}{l}118 \text { / } 184 \text { / } 319(342) \\
2.09 \text { / } 3.41 / 5.84(6.66)\end{array}$ \\
\hline $\begin{array}{l}\text { Access to } \\
\text { public } \\
\text { transportation }\end{array}$ & $\begin{array}{l}\text { Available fleet per street length [n/h/1000km] } \\
\text { PT capacity per street length [pax/h/km] } \\
\text { Available fleet per urban area [n/h/km2] } \\
\text { PT capacity per urban area [1000 pax/h/km2] } \\
\text { PT stops per street length [n/1000 km] } \\
\text { PT capacity per population area [pax/hab] }\end{array}$ & $\begin{array}{l}799 \text { / } 1036 \text { / } 1279(1072) \\
1106 \text { / } 1668 \text { / } 2583(2477) \\
17.6 \text { / } 23.1 / 28.4(24.1) \\
24 \text { / } 36 \text { / } 56(56) \\
799 \text { / } 1036 \text { / } 1279(1072) \\
1.7 / 2.9 / 5.9(7.5)\end{array}$ \\
\hline
\end{tabular}

Table 2 - Comparison matrix between Al-macro indicators and elicited weights

\begin{tabular}{l|c|c|c|c|c}
\hline & $\begin{array}{c}\text { Integrity of } \\
\text { road network }\end{array}$ & $\begin{array}{c}\text { Diversity of } \\
\text { land use }\end{array}$ & Education & $\begin{array}{c}\text { Road } \\
\text { safety }\end{array}$ & $\begin{array}{c}\text { Access to } \\
\text { pub. transp. }\end{array}$ \\
\hline Integrity of road network & - & 0.20 & 0.33 & 4.00 & 0.25 \\
Diversity of land use & 5.00 & - & 5.00 & 5.00 & 3.00 \\
Education & 3.00 & 0.20 & - & 5.00 & 0.33 \\
Road safety & 0.25 & 0.20 & 0.20 & - & 0.20 \\
Access to public transp. & 4.00 & 0.33 & 3.00 & 5.00 & - \\
Elicited weight & 0.08 & 0.47 & 0.15 & 0.05 & 0.26 \\
\hline
\end{tabular}


Figure 2 - Categories of attractiveness for pedestrian movements at the city level

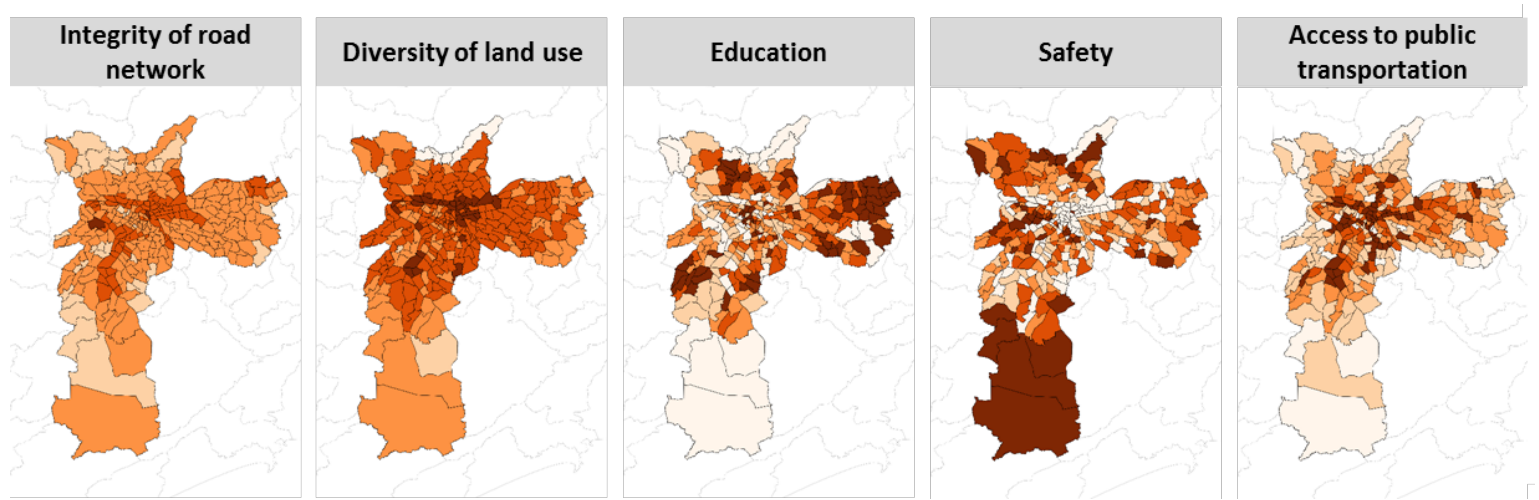

Note: for a representation of the composition of the Al-macro, cf. Figure 3.

Note:

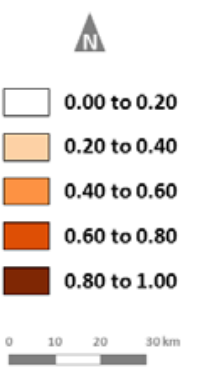

Figure 3 - Values of the Al-macro for each OD zone

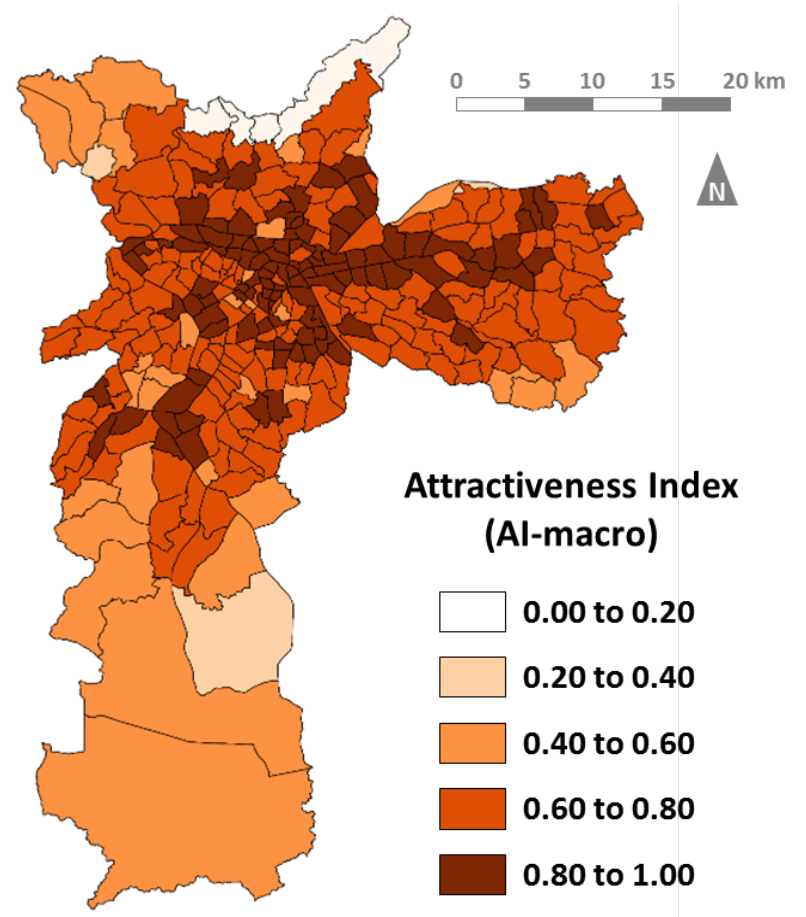

Higher values in the different categories of attractiveness (dark orange colors), in Figure 2, represent a higher contribution towards the attractiveness index (AI-macro), in Figure 3. By analyzing the maps in Figure 2, we can see that the "Integrity of road network", "Diversity of land use", and "Access to public transportation" are concentrated in the city center, while Education and Safety present mainly the opposite spatial pattern, with higher values in the city periphery.

The prominence of the city's southern region on road safety can be justified by its particular rural 
characteristic, which concentrates a high number of expressways in low-populated areas with large water bodies and natural reserves. Since this category of the AI-macro is greatly based on the rate of road crashes per street length, the particular aspect of this region may have affected the estimation of the safety measures towards higher values.

Once composed, the AI-macro can be compared to the proportion of pedestrian movements within the OD zones; therefore, the relationship of the measured attractiveness at the city level with the pedestrian movements was sought. To do this, the Comparison Index (CI) was proposed to assess the relationship between the achieved pedestrian movements and the potential attractiveness of pedestrians (Eq. 1).

$C I=\frac{\text { Share of pedestrians movements }}{A I-\text { macro }}$

A higher CI value indicates a greater detachment between the share of pedestrian movements and the AI-macro within the OD zone. A lower CI value indicates a more aligned relationship between the AI-macro and the share of the pedestrian trips, i.e., the attractiveness of the built environment as represented by the AI-macro is in agreement with the share of pedestrian movements within each OD zone. However, different levels of detachment between the two measurements were identified, as presented in Figure 4.
The spatial distribution of the CI thus indicates different influences of the built environment on the motivations to walk throughout the city in addition to the assessment of some aspects of social inequality related to walking, which will be discussed in the next section.

The CI is also convenient for the identification of the most adequate OD zones to perform surveys at the street level since it works as a proxy of heterogeneity of the association of the built environment with the share of pedestrian movements. Taking advantage of the administrative division in the city of São Paulo in subprefectures and the compatibility with the OD zones' boundaries, regions with the highest variations in the CI were pursued. In this way, OD zones with different CIs could be surveyed to seek answers to the different levels of detachment between the share of pedestrian movements and the pedestrian AI at the city level (AI-macro). In this regard, the pedestrian $\mathrm{AI}$ at the neighborhood level (AI-micro) was proposed and applied to eight OD zones at the Subprefecture of Sé, in the downtown area ( $c f$. selected zones in Figure 4). This region was selected because it yielded the largest difference between the obtained CIs for the OD zones and presents a consolidated urban fabric, which could be assessed further through data collection at the neighborhood level.

Figure 4 - Development of the Comparison Index (CI) from the proportion of pedestrian movements (on the upper left) and the city level Attractiveness Index (Al-macro, on the lower left). The inset shows selected OD zones to develop the neighborhood-level pedestrian Attractiveness Index (Al-micro)

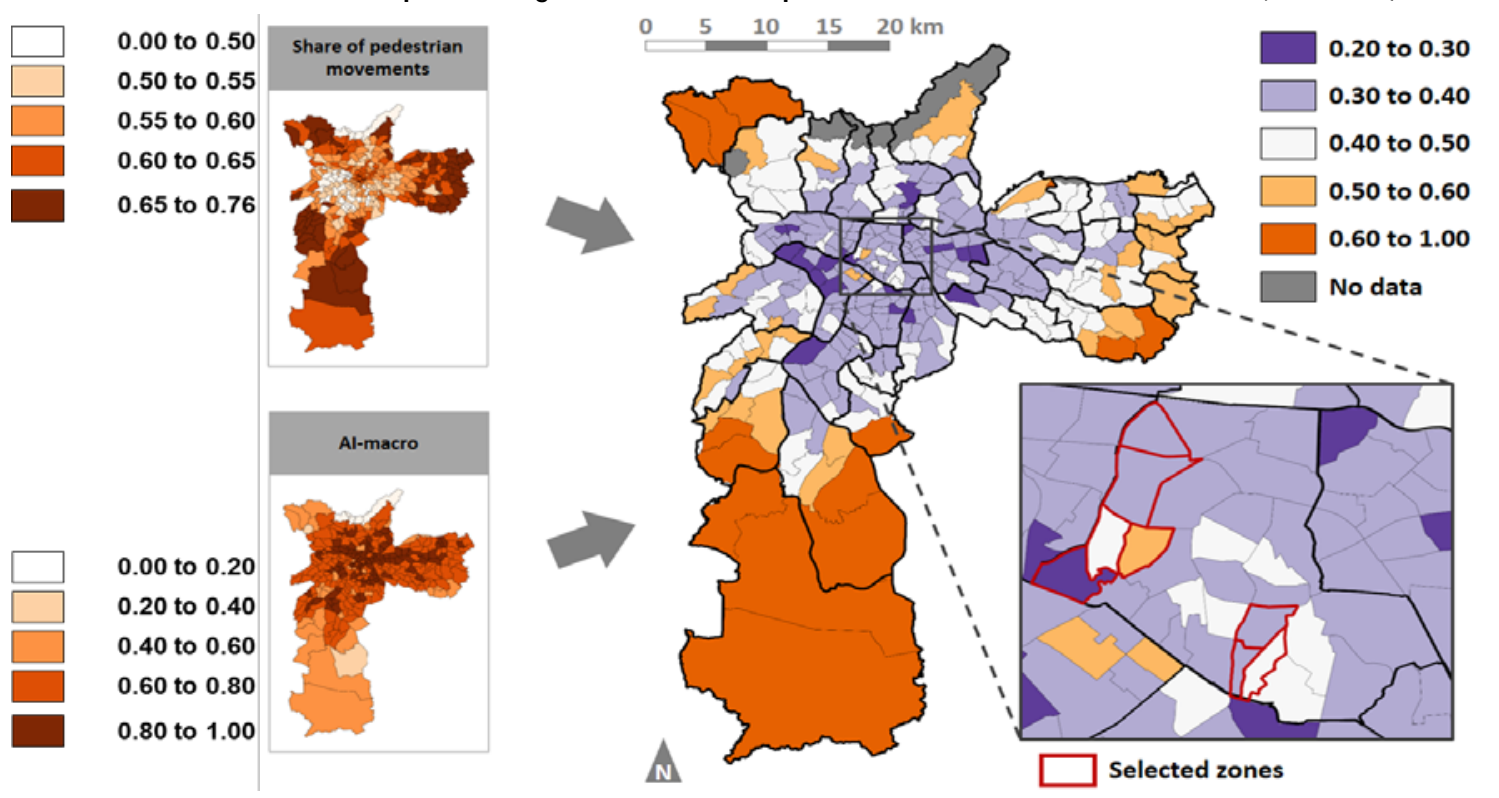




\section{Neighborhood-level pedestrian Attractiveness Index (Al-micro)}

At the neighborhood level, the development of a pedestrian AI required metrics at scales smaller than most of the available datasets, which demanded the development of indicators through data collection at the street level. In search of open-source and userfriendly devices that lead to a shorter duration of surveys and lower associated costs, the primary data gathering methods combined functionalities from open-source QGIS software and Google Maps devices (Street View and MyMaps) that could be easily adopted by advocacy and public stakeholders (BLEČIĆ et al., 2015). Eight parameters were surveyed in 829 features (street links) in the selected OD zones ( $c f$. Figure 5), resulting in 82 kilometers of road network. The considered parameters included the physical characteristics of sidewalks (existence, width, continuity, and quality of pavement) and the aspects of the pedestrian surroundings (vegetation coverage, road signage, active façades, and number of traffic lanes), convergent with similar researches (MAGHELAL;
CAPP, 2011; CAMBRA, 2015; STOCKTON et al., 2016).

Within the selected OD zones, the physical characteristics of sidewalks and the aspects of the pedestrian surroundings were collected according to Table 3.

The data collection yielded values of each component that portray the characteristics of the pedestrian environment in the selected OD zones at the neighborhood level, as indicated in Table 4.

Similarly, the AHP additive aggregation method was adopted to elaborate a single attractiveness metric through pairwise comparisons between the gathered indicators, which also yielded consistent results, according to Table 5, with Consistency Ratio equal to $5.0 \%$, which is considered consistent (SAATY, 1990; WEDLEY, 1993). Two attributes comprised $56 \%$ of the assigned weights and were considered therefore the most relevant for pedestrian policy at the neighborhood level: active façade (32\%) and continuity of sidewalks (24\%). The matrix obtained for the comparison of the AImicro components is indicated in Table 5.

Figure 5 - Selected OD zones whose data was collected at the neighborhood level

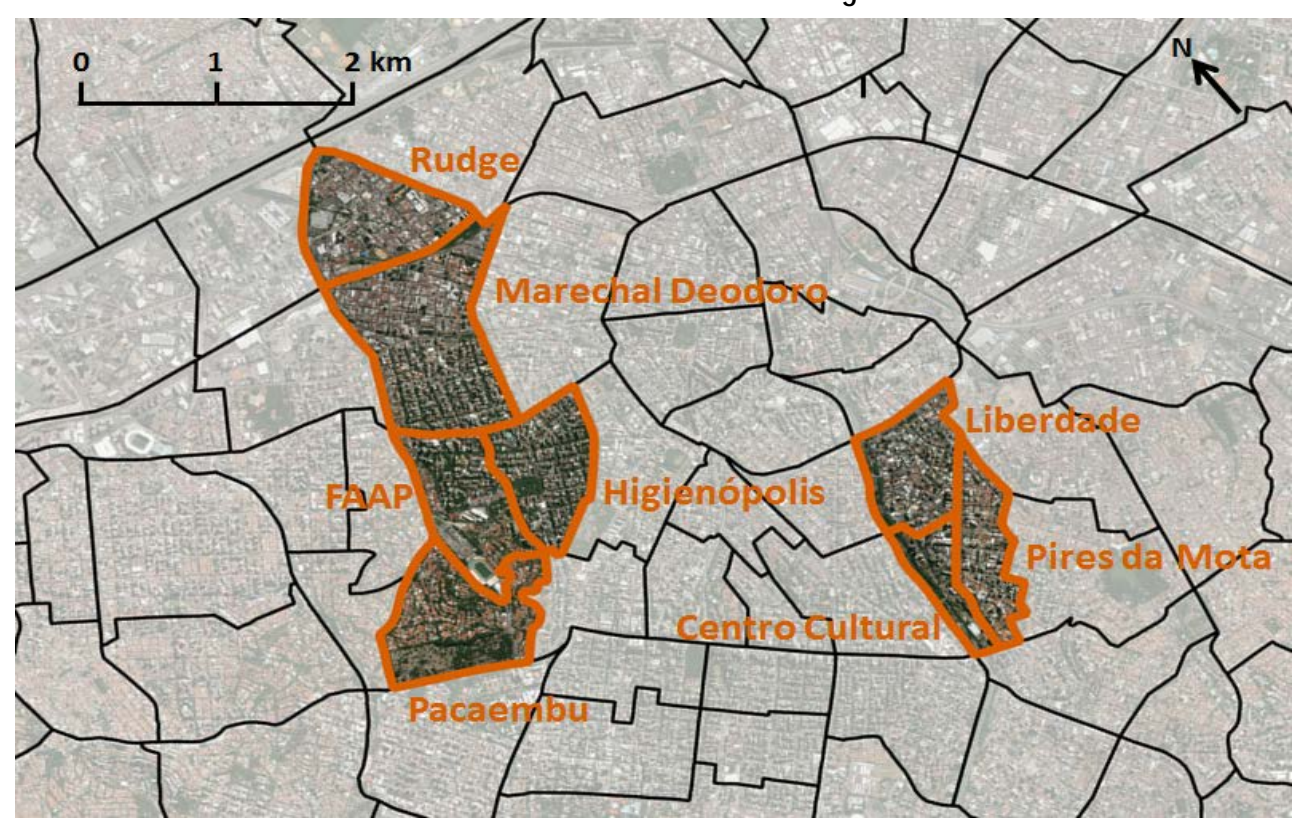


Table 3 - Eight categories and their codification that guided the development of the Al-micro

\begin{tabular}{|c|c|}
\hline Category & Codification (description) \\
\hline $\begin{array}{l}\text { Existence of } \\
\text { sidewalks }\end{array}$ & $\begin{array}{l}0 \text { - No sidewalks } \\
1 \text { - Sidewalk on only one side of the road } \\
2 \text { - Sidewalks on both sides of the road }\end{array}$ \\
\hline $\begin{array}{l}\text { Width of } \\
\text { sidewalks }\end{array}$ & Approximate dimension in meters, discretized every 0.5 meter. \\
\hline $\begin{array}{l}\text { Quality of } \\
\text { sidewalk } \\
\text { pavement }\end{array}$ & $\begin{array}{l}0 \text { - Poor (no pavement or poor quality in practically the whole extension of the sidewalk) } \\
1 \text { - Bad (pavement in poor quality in most stretches of the sidewalk) } \\
2 \text { - Regular (pavement with similar proportion between good and poor quality) } \\
3 \text { - Good (pavement with few stretches in poor quality) }\end{array}$ \\
\hline $\begin{array}{l}\text { Sidewalk } \\
\text { continuity }\end{array}$ & $\begin{array}{l}0 \text { - Sidewalk without any continuity: pedestrian is forced to walk off the sidewalk in most } \\
\text { of its extension } \\
1 \text { - Sidewalk with almost no continuity: pedestrian is brought to walk off the sidewalk in } \\
\text { great part of the path } \\
2 \text { - Pedestrians can walk entirely on the sidewalk, but still have to make significant } \\
\text { deviations } \\
3 \text { - Pedestrians must make a few deviations along the sidewalk } \\
4 \text { - Pedestrians can do their route along the sidewalk without significant deviations }\end{array}$ \\
\hline $\begin{array}{l}\text { Narrowness } \\
\text { of } \\
\text { the roadway }\end{array}$ & $\begin{array}{l}\text { Inversely proportional to the number of road lanes in both directions of the road: } \\
0 \text { - Four (4) road lanes or more } \\
1 \text { - Three (3) road lanes } \\
2 \text { - Two (2) road lanes } \\
\text { 3- One (1) road lane } \\
4 \text { - no road lane (pedestrian zone) }\end{array}$ \\
\hline $\begin{array}{l}\text { Vegetation } \\
\text { coverage }\end{array}$ & $\begin{array}{l}0 \text { - No trees along the sidewalk } \\
1 \text { - Few trees along the sidewalk } \\
2 \text { - Similar proportion of stretches with and without trees } \\
3 \text { - Much of the extension of the sidewalk covered with trees } \\
4 \text { - Trees covering along the entire sidewalk }\end{array}$ \\
\hline $\begin{array}{l}\text { Road } \\
\text { signage for } \\
\text { pedestrians }\end{array}$ & $\begin{array}{l}0 \text { - No signage } \\
1 \text { - Horizontal signaling only } \\
2 \text { - Horizontal and vertical signaling } \\
3 \text { - Horizontal and vertical signaling, traffic lights } \\
4 \text { - Horizontal and vertical signaling, traffic lights, pedestrian signs }\end{array}$ \\
\hline $\begin{array}{l}\text { Active } \\
\text { façade }\end{array}$ & $\begin{array}{l}0 \text { - No buildings with active façades along the entire extension of the sidewalk } \\
1 \text { - Up to } 20 \% \text { of the extension of the sidewalk present buildings with active façade } \\
2 \text { - } 20 \% \text { to } 40 \% \text { of the ext. of the sidewalk present buildings with active façade } \\
3 \text { - } 40 \% \text { to } 60 \% \text { of the ext. of the sidewalk present buildings with active façade } \\
4 \text { - More than } 60 \% \text { of the ext. of the sidewalk present build. with active façade }\end{array}$ \\
\hline
\end{tabular}

Table 4 - Median value and range (in brackets) of the Al-micro components within the selected OD zones

\begin{tabular}{c|c|c|c|c|c|c|c|c}
\hline OD zone & $\begin{array}{c}\text { Exist. of } \\
\text { sidewalks }\end{array}$ & $\begin{array}{c}\text { Width of } \\
\text { sidewalks }\end{array}$ & $\begin{array}{c}\text { Quality of } \\
\text { sidew. } \\
\text { pav. }\end{array}$ & $\begin{array}{c}\text { Sidewalk } \\
\text { continuity }\end{array}$ & $\begin{array}{c}\text { No. of } \\
\text { lanes* }\end{array}$ & $\begin{array}{c}\text { Veget. } \\
\text { coverage }\end{array}$ & $\begin{array}{c}\text { Road } \\
\text { sign. for } \\
\text { ped. }\end{array}$ & $\begin{array}{c}\text { Active } \\
\text { façade }\end{array}$ \\
\hline FAAP & $2(1-2)$ & $2.5(0.5-4)$ & $2(1-4)$ & $2(0-4)$ & $2(1-5)$ & $2(0-4)$ & $1(0-3)$ & $0(0-3)$ \\
Higienópolis & $2(2-2)$ & $3(2-3.5)$ & $3(1-4)$ & $2(0-3)$ & $2(0-4)$ & $3(0-4)$ & $1(0-2)$ & $0(0-3)$ \\
Mal. Deodoro & $2(0-2)$ & $2.5(0-4)$ & $3(0-4)$ & $3(0-4)$ & $2(1-4)$ & $1(0-4)$ & $1(0-3)$ & $1(0-4)$ \\
Pacaembu & $2(1-2)$ & $2(1-3.5)$ & $2(1-3)$ & $1(0-3)$ & $2(1-3)$ & $3(0-4)$ & $0(0-1)$ & $0(0-1)$ \\
Rudge & $2(0-2)$ & $2(0-4)$ & $2(0-4)$ & $2(0-4)$ & $2(0-5)$ & $1(0-4)$ & $1(0-3)$ & $0(0-2)$ \\
Cto. Cultural & $2(1-2)$ & $2(1-4)$ & $3(1-4)$ & $2(1-4)$ & $2(1-5)$ & $2(0-4)$ & $1(0-3)$ & $0(0-4)$ \\
Liberdade & $2(0-2)$ & $2(0-5)$ & $3(0-4)$ & $2(0-4)$ & $2(1-6)$ & $1(0-4)$ & $1(0-3)$ & $1(0-4)$ \\
Pires da Mota & $2(2-2)$ & $2.5(1-4)$ & $3(2-4)$ & $4(1-4)$ & $2(1-4)$ & $1(0-4)$ & $1(0-4)$ & $1(0-4)$ \\
Total & $2(0-2)$ & $2.5(0-5)$ & $3(0-4)$ & $2(0-4)$ & $2(0-6)$ & $2(0-4)$ & $1(0-4)$ & $0(0-4)$ \\
\hline
\end{tabular}

Note: *indicates the number of lanes, which is a primary source for the estimation of the narrowness of the roadway. 
Table 5 - Comparison matrix between Al-micro components and elicited weights

\begin{tabular}{l|c|c|c|c|c|c|c|c}
\hline & 1.WS & 2.QP & 3.SC & 4.NR & 5.VC & 6.SP & 7.AF & 8.ES \\
\hline 1. Width of sidewalks (WS) & - & 0.20 & 0.14 & 0.33 & 0.20 & 0.20 & 0.11 & 1.00 \\
2. Quality of sidewalk pav. (QP) & 5.00 & - & 0.33 & 1.00 & 1.00 & 1.00 & 0.20 & 6.00 \\
3. Sidewalk continuity (SC) & 7.00 & 3.00 & - & 5.00 & 3.00 & 1.00 & 1.00 & 8.00 \\
4. Narrowness of the roadway (NR) & 3.00 & 1.00 & 0.20 & - & 0.25 & 1.00 & 0.14 & 4.00 \\
5. Vegetation coverage (VC) & 5.00 & 1.00 & 0.33 & 4.00 & - & 1.00 & 0.20 & 5.00 \\
6. Road signage for ped. (SP) & 5.00 & 1.00 & 1.00 & 1.00 & 1.00 & - & 0.50 & 4.00 \\
7. Active façade (AF) & 9.00 & 5.00 & 1.00 & 7.00 & 5.00 & 2.00 & - & 8.00 \\
8. Existence of sidewalks (ES) & 1.00 & 0.17 & 0.12 & 0.25 & 0.20 & 0.25 & 0.12 & - \\
Elicited weight & 0.02 & 0.10 & 0.24 & 0.07 & 0.12 & 0.12 & 0.32 & 0.02 \\
\hline
\end{tabular}

The collected attributes were then additively aggregated by feature (road link), according to the multicriteria weights and then by OD zone, weighted according to the road length. This resulted in the pedestrian $\mathrm{AI}$ at the neighborhood level (AImicro). Similar to the city-level index (AI-macro), the AI-micro could be compared to the share of pedestrian movements within the OD zones, which yielded the results that are presented in the following section.

The methodology previously described is summarized schematically in Figure 6.

\section{Results and discussion}

Through the different levels of adherence of the city-level pedestrian AI (AI-macro) with the effective realization of pedestrian movements, the CI highlights the inappropriateness of a single attractiveness metric to represent the influence of the built environment on the motivations to walk in different parts of the city. Moreover, the CI enables the assessment of some aspects of social inequality related to walking: lower CI values indicate zones with individuals that walk little, although living in a rather attractive neighborhood (around the city center and along the economic and business expansion area in the southwest zone), and higher CI values reveal regions that, despite having poorly walkable conditions, present very high shares of walking (especially in the low income outskirts). The value of CI is proportional to the share of pedestrian movements and inversely proportional to the AI-macro. In this sense, a lower CI can be obtained both by increasing the AI-macro value and lowering the share of pedestrian movements.

Figure 7 presents some east zones with low income profiles that have high CI values (dark orange colors); most of the zones closer to the Central Business District have low CI values (dark blue). In transport planning, this can assist the definition of specific public policies. In zones with higher CI values, policies should be oriented towards the qualification and upgrading of existing pedestrian movements since these movements occur in rather inadequate conditions for pedestrians. In regions with lower CI values where the built environment presents a rather consolidated level, the low performance in the share of pedestrian movements can be addressed through activities that seek to promote walking as a mode of transportation, e.g., advocacy and campaigns on pedestrian mobility.

The analysis of the proportion of pedestrian movements and the proposed AIs (AI-macro and AI-micro, i.e., at the city and at the neighborhood level) raise some questions concerning pedestrian behavior in the urban environment: should greater attractiveness of the built environment be correlated with higher pedestrian shares? The CI indicates no correlation between the two variables at the city level. To verify whether the detachment observed through the CI also applies to the neighborhoodlevel index (AI-micro), a new assessment was proposed. Four econometric models were proposed to assess the relationship between the share of pedestrian movements (dependent variable) and the obtained measures:
(c) with AI-macro only (model 1);
(d) AI-macro and AI-micro (model 2);
(e) AI-micro only (model 3); and
(f) the logarithmic transformation of AI-micro (model 4).

As stated by the CI, the AI-macro is not a good predictor of the share of pedestrian movements. However, the composition of the AI-macro and AImicro presents a much-improved goodness-of-fit, with an adjusted $\mathrm{R}^{2}$ increased to 0.760 . The Model 3 with only AI-micro yields better results (adjusted $\left.R^{2}=0.797\right)$, which fit even better with the adoption of the logarithmic transformed AI-micro i.e., ln (AImicro), as presented in Table 6 . 
Figure 6 - Schematic representation of the adopted methodological steps

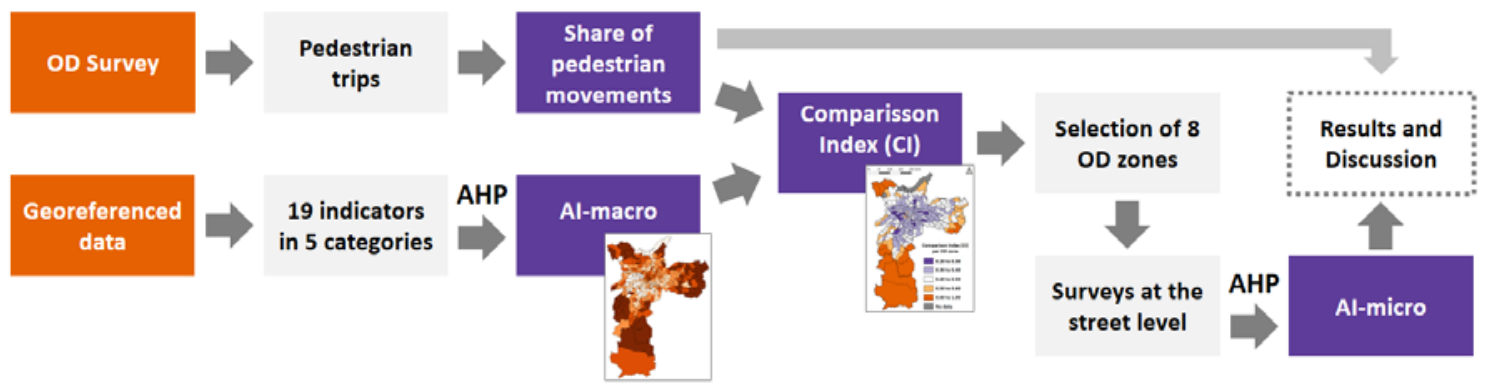

Figure 7 - Interpretation of the Comparison Index results for addressing strategies in pedestrian environments

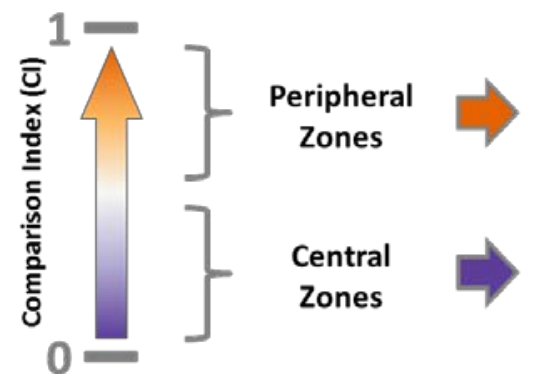

High proportion of pedestrian

movements and low quality of the built environment

Low proportion of pedestrian movements and high quality of the built environment

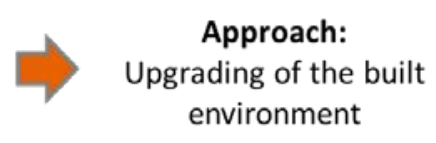

Approach:

Encouragement of pedestrian movements

Note: for interpretation of the color references in this figure legend, the reader is referred to the web version of this article.

Table 6 - Relevant goodness-of-fit measures (above dashed line) and coefficients of inserted dependent variables (below dashed line) for linear regression models (dependent variable: share of pedestrian movements)

\begin{tabular}{l|c|c|c|c}
\hline & Model 1 & Model 2 & Model 3 & Model 4 \\
\hline Adjusted R & -0.009 & 0.760 & 0.797 & 0.861 \\
Durbin-Watson & 1.787 & 2.716 & 2.818 & 2.820 \\
F (ANOVA) & 0.935 & $12.096^{* *}$ & $28.474^{* * *}$ & $44.430^{* * *}$ \\
\hline (constant) & $0.418^{* *}$ & 0.193 & $0.206^{* *}$ & $0.848^{* * *}$ \\
AI-macro & 0.172 & 0.026 & & \\
AI-micro & & 0.798 & $0.816^{* * *}$ & \\
ln (AI-micro) & & & & $0.337^{* * *}$ \\
\hline
\end{tabular}

Note: *, ** and *** show significance at a level of $10 \% 5 \%$ and $1 \%$ respectively.

Regarding the verification of the distribution of disturbances, only model 1 presents no normality of the disturbances and certain heteroscedasticity of disturbances with the predicted values. Regarding the non-autocorrelation of disturbances, indicated by values of the Durbin-Watson statistics around 2.0 (WASHINGTON; KARLAFTIS; MANNERING, 2010), the models yielded values between 1.8 and 2.6, thus indicating that no strong autocorrelation is present.

The results therefore reveal that indicators at the neighborhood level, such as active façade and sidewalk continuity, may be better predictors of the share of pedestrian movements than the ones at the city level, such as diversity of land use and access to public transportation, which are highlighted in similar studies (MARINS, 2017). Moreover, they seem to highlight some aspects concerning the way in which the proportion of pedestrian movements relate with the built environment. The logarithmlike relationship between the two variables suggest that upgrades in attractiveness indicators in poorly qualified areas would perform better in terms of an increase in pedestrian shares than the ones that already present high scores in the same region. This relationship is similarly outlined in recent studies (CAMBRA, 2015).

Among the obtained models, although presenting the greatest fit and inserting the transformed variable ln (AI-micro), model 4 presents an estimated constant that does not seem reasonable: the range of AI-micro values, i.e., from 0 to 1 , 
results in non-consistent pedestrian shares, between 0.85 and 1.33. Therefore, model 3 is selected to better predict the share of pedestrian movements. Besides presenting relevant goodness-of-fit measures in the model validation (i.e., adjusted $\mathrm{R}^{2}$ of 0.827 and similar estimated coefficients in $20 \%$ of the sample data), model 3 indicates interesting outcomes concerning the attractiveness of the built environment and the modal share. Areas with the minimal conditions for walking, i.e., an AI-micro equal to 0 (zero), nevertheless present $21 \%$ of movements made by foot, whereas optimal conditions of attractiveness in a region, i.e., an AImicro equal to 1 , lead to pedestrian shares of $97 \%$.

\section{Conclusions}

In the search for the incorporation of pedestrian mobility into transport policies, the attractiveness of the built environment was believed to endorse the elaboration of methods focused on active modes of transportation. By relating the OD survey pedestrian data of São Paulo (Brazil) with the proposed pedestrian $\mathrm{AI}$ at the city level (AI-macro), it was possible to develop an indicator, the Comparison Index (CI), to guide two types of strategies for upgrading the built environment. High CI values suggest prioritizing the upgrading of existing pedestrian movements performed under inadequate conditions (mostly in the low income outskirts), and low CI values indicate a better match of strategies for promoting walking (e.g. marketing, advocacy, campaigns) in regions with a low pedestrian share and a rather consolidated infrastructure (mostly located around the city center).

The assessment of the built environment was hence conducted at the neighborhood level (AI-micro), which yielded a strong positive correlation (adjusted $\mathrm{R}^{2}=0.797$ ) with the share of pedestrian movements, thus indicating the potential of aggregated measures at the scale of the neighborhood to reveal a correlation with the performance of walking movements. Besides highlighting the importance of collecting data at lower scales (e.g., the street and the neighborhood) to guide suitable pedestrian-oriented strategies, the findings also indicate different attractiveness indexes according to the region of the city and to pedestrian groups, possibly due to different perceptions, as suggested in recent findings (MOURA; CAMBRA; GONÇALVES, 2017).

The adopted aggregation method to compose the Attractiveness Indexes (AI-macro and AI-micro) was found to be appropriate to indicate the fundamental role of three factors in attracting pedestrian movements: active façade, narrowness of streets, and sidewalk continuity. These factors differ from the usually emphasized width of the sidewalks as the single indicator for upgrading sidewalks. A major limitation of this method concerns its unsuitability to observe important differences in the evaluation of the built environment parameters according to gender. As indicated by Harkot et al. (2017), the selection of the parameters and the assignment of weights were performed by male researchers only. When evaluated by female researchers, the set of categories resulted in a greater importance associated to the active façade (40\%) and the narrowness of roadways (23\%), in which the analysis yielded lower values of the AI-micro in all OD zones from the perspective of women (ibid.).

The pertinence of the active façade in pedestrian assessments here identified demands nevertheless special attention in further studies. Although the selected OD zones were located in a consolidated area and close from each other, the proposed measures might not fully reflect possible spatial idiosyncrasies, such as the contrast between a typical residential only zone (e.g. Pacaembu) and a commercial district (e.g. Liberdade). The consideration of distinct urban contexts (such as low-income communities, industrial districts, and university campuses) might then underlie analyses at the neighborhood level that are stratified by land use.

To develop further studies, some suggestions are proposed:

(a) continuity of data collection at the neighborhood level in OD zones of other regions (subprefectures);

(b) the appraisal of alternative data collection methods that properly consider the scale and viewpoint of pedestrians;

(c) the collection of pedestrian movement data instead of their estimation from the provided pedestrian trips;

(d) the consideration of non-compensatory, i.e., non-additive aggregation methods, to compose the proposed AI; and

(e) the adoption of participatory assessment methods that consider gender-related issues and subjective dimensions of pedestrians, as well as other relevant aspects for the appreciation of disparities in pedestrian mobility. 


\section{References}

ACKERSON, K. J. A GIS Approach to Evaluating Streetscape and Neighbourhood Walkability. 2005. $103 \mathrm{f}$. Master of Community and Regional Planning - University of Oregon, 2005.

\section{AMANCIO, M. A. Relacionamento Entre a} Forma Urbana e as Viagens a Pé. São Carlos, 2005. 100 f. Dissertação (Mestrado em Engenharia Urbana) - Escola de Engenharia, Universidade Federal de São Carlos, 2005.

ASSOCIAÇÃO NACIONAL DE TRANSPORTES PÚBLICOS. Sistema de Informações da Mobilidade Urbana: relatório geral. São Paulo: ANTP, 2015.

BLEČIĆ, I. et al. Walkability and Urban Capabilities: evaluation and planning decision support. Agenzia Entrate (Italia), 2015.

BRADSHAW, C. Creating - and Using - a Rating System for Neighbourhood Walkability: towards an agenda for "Local Heroes". In: INTERNATIONAL PEDESTRIAN CONFERENCE, 14., Boulder, 1993. Proceedings... Boulder, 1993.

CAMBRA, P. Pedestrian Accessibility and Attractiveness for Walkability Assessment. Master thesis. Instituto Superior Técnico da Universidade de Lisboa, 2012.

CAMBRA, P. A Walkability Assessment Framework That Works? The issue of validation methods and results. In: WALK21, 16., Vienna, 2015. Proceedings... Vienna, 2015.

CERVERO, R.; KOCKELMAN, K. Travel Demand and the 3Ds: density, diversity, and design. Transportation Research Part D: Transport and Environment, v. 2, n. 3, p. 199219, 1997.

CERVERO, R. et al. Influences of Built Environments on Walking and Cycling: lessons from Bogotá. International Journal of Sustainable Transportation, v. 3, n. 4, p. 203226, 2009.

CRANEA, R.; CREPEAUB, R. Does Neighborhood Design Influence Travel? Behavioral Analysis of Travel Data and GIS Data. Transportation Research Part D: Transport and Environment, v. 3, n. 4, p. 225-238, 1998.

CRUZ, D. A. et al. Estruturação do Caminho de Pedestres (Structuring of pedestrian routes). São Paulo, 2015. Trabalho de Conclusão do Curso (Engenharia Civil) - Escola Politécnica, Universidade de São Paulo, 2015.
FITZPATRICK, K. et al. Improving Pedestrian Safety at Unsignalized Crossings. Transportation Research Board. TCRP Report 12 / NCHRP report 562. Washington, D.C., 2006.

GRIECO, E. P.; PORTUGAL, L. S.; ALVES, R. M. Aplicação de Um Índice do Ambiente Construído Para Avaliação da Mobilidade Sustentável. Ambiente Construído, Porto Alegre, v. 16, n. 4, p. 215-225, out./dez. 2016.

GONÇALVES, J. E. L. Áreas de Pedestres: conceitos. São Paulo: Companhia de Engenharia de Tráfego, 1978.

HARKOT, M. K. et al. Gênero e Andar a Pé: a qualidade do ambiente construído incentiva igualmente mulheres e homens a caminhar? In: ANDRADE, V.; LINKE, C. Caminhabilidade no Brasil. Rio de Janeiro: Babilonia Cultura Editorial, 2017.

KRIZEK, K. J. Operationalizing Neighborhood Accessibility for Land Use: travel behavior research and regional modeling. Journal of Planning Education and Research, v. 22, n. 3, p. 270-287, 2003.

KRIZEK, K. J.; HANDY, S. L.; FORSYTH, A. Explaining Changes in Walking and Bicycling Behavior: challenges for transportation research. Environment and Planning B: Urban Analytics and City Science, v. 36, n. 4, p. 725-740, 2009.

LEE, G. K. L.; CHAN, E. H. W. The Analytic Hierarchy Process (AHP) Approach for Assessment of Urban Renewal Proposals. Social Indicators Research, v. 89, n. 1, p. 155-168, 2008.

MAGHELAL, P. K.; CAPP, C. J. Walkability: a review of existing pedestrian indices. URISA Journal, v. 23, n. 2, p. 5-20, 2011.

MARINS, K. R. de C. C. Análise Comparativa Multicriterial de Estratégias em Sustentabilidade Urbana Aplicada aos Bairros de Cidade Pedra Branca (Palhoça, SC) e Vauban (Freiburg, Alemanha). Ambiente Construído, Porto Alegre , v. 17, n. 1, p. 393-408, jan./mar. 2017.

METRÔ (São Paulo). Manual da Pesquisa Domiciliar: Pesquisa de Mobilidade da Região Metropolitana de São Paulo, 2012. São Paulo, 2013. Available in:

$<$ https://edisciplinas.usp.br/pluginfile.php/3502431 /mod_resource/content/0/manual\%20domiciliar_2 012.pdf>. Access in: 20 may 2018. 
METRÔ (São Paulo). Pesquisa Origem e Destino 2007: Síntese das Informações / Pesquisa Domiciliar. São Paulo, 2008. Available in: $<$ http://www.metro.sp.gov.br/pesquisaod/arquivos/OD_2007_Sumario_de_Dados.pdf $>$. Access in: 17 maio 2018.

MICHAEL, Y. L.; GREEN, M. K.; FARQUHAR, S. A. Neighborhood Design and Active Aging. Health \& Place, v. 12, n. 4, p. 734-740, 2006.

MOURA, F.; CAMBRA, P.; GONÇALVES, A. B. Measuring Walkability for Distinct Pedestrian Groups with a Participatory Assessment Method: a case study in Lisbon. Landscape and Urban Planning, v. 157, p. 282-296, 2017.

\section{NZ TRANSPORT AGENCY. Pedestrian} Planning and Design Guide. Wellington, 2009. Available in: $<$ https://www.nzta.govt.nz/resources/pedestrianplanning-guide/>. Access in: 20 maio 2018.

PAIXÃO, R. C. da; DELGADO, J. P. M. Análise Espacial das Condições de Deslocamento do Pedestre na Integração Com o Transporte Público. In: ANPET - CONGRESSO DE ENSINO E PESQUISA EM TRANSPORTES, 28., Curitiba, 2014. Anais... Curitiba, 2014.

PARTHASARATHI, P.; LEVINSON, D.; HOCHMAIR, H. Network Structure and Travel Time Perception. PLoS One 8 (10): e77718. University of Gävle, Sweden, 2013.

PASSMORE, D. The Missing leg: the experience of walking to public transit in Sao Paulo, Brazil. Toronto? University of Toronto, 2007.

RODRIGUES, A. R. P. et al. Indicators for Urban Design and Their Relationship with the Propensity to walk. Journal of Transport Literature, Manaus, v. 8, n.3, p. 62-68. 2014.

SAATY, T. L. How to Make a Decision: the Analytic Hierarchy Process. European Journal of Operational Research, v. 48, n. 1, p. 9-26, 1990.

STOCKTON, J. et al. Development of a Novel Walkability Index for London, United Kingdom: cross-sectional application to the Whitehall II Study. BMC Public Health, p. 1-12, 2016.
TALEN, E.; KOSCHINSKY, J. The Walkable Neighborhood: a literature review. International Journal of Sustainable Land Use and Urban Planning, v. 1, n. 1, p. 42-63, 2013.

VALE, D. S.; PEREIRA, M. The Influence of the Impedance Function on Gravity-Based Pedestrian Accessibility Measures: a comparative analysis. Environment and Planning B: Urban Analytics and City Science, v. 44, n. 4, p. 740-763, 2016.

VASCONCELLOS, E. A. Andar nas Cidades do Brasil. Caminhabilidade no Brasil. 2017. In: ANDRADE, V.; LINKE, C. Caminhabilidade no Brasil. Rio de Janeiro: Babilonia Cultura Editorial, 2017.

VASCONCELLOS, E. A.; MENDONÇA, A. Observatorio de Movilidad Urbana: informe 20152016 (Resumen Ejecutivo). CAF Banco de Desarrollo de América Latina. Caracas, 2017. Available in:

<http://scioteca.caf.com/handle/123456789/981>. Access in: 20 maio 2018.

WASHINGTON, S.; KARLAFTIS, M.; MANNERING, F. Statistical and Econometric Methods for Transportation Data Analysis. $2^{\text {nd }}$. ed. Boca Raton? Chapman and Hall/CRC, 2010.

WEDLEY, W. C. Consistency Predictions for Incomplete AHP Matrices. Mathematical and Computer Modelling, v. 17, n. 4/5, p. 151-161, 1993.

\section{Acknowledgements}

The authors thank the anonymous reviewers for their careful reading of our manuscript and for the valuable comments and suggestions that helped improve this work. Also, the meticulous reading by Lucas F. C. R. Marte was very helpful in the revision process.

This study was partly financed by the Brazilian Coordination for the Improvement of Higher Education Personnel (CAPES), Finance Code no. 001. The first author thanks the financial support from the Portuguese Foundation for Science and Technology (FCT, PD/BD/128057/2016). The third author would like to thank the financial support from the Brazilian National Council for Scientific and Technological Development (CNPq, 428005/2016-0). The authors declare no competing financial interests. 


\section{Mateus Humberto}

Instituto Superior Técnico ${ }^{1}$ Universidade de Lisboa | Av. Rovisco Pais, 1 | Lisboa - Portugal | Tel.: +(351) 218419865 | E-mail: mateushumberto@gmail.com

\section{Rodrigo Laboissière}

Escola Politécnica | Universidade de São Paulo | Av. Prof. Almeida Prado, n. 83 | São Paulo - SP - Brasil | E-mail: rodrigolaboissiere@gmail.com

\section{Mariana Giannotti}

Escola Politécnica | Universidade de São Paulo | E-mail: mariana.giannotti@usp.br

\section{Cláudio Luiz Marte}

Escola Politécnica | Universidade de São Paulo | Tel.: (11) 99918-3655 | E-mail: claudio.marte@usp.br

\section{Daniel Agostini Cruz}

Escola Politécnica | Universidade de São Paulo | E-mail: daniel.cruz1@usp.br

\section{Henrique Primon}

Escola Politécnica | Universidade de São Paulo | E-mail: henrique.primon@usp.br

\section{Revista Ambiente Construído}

Associação Nacional de Tecnologia do Ambiente Construído

Av. Osvaldo Aranha, 99 - 30 andar, Centro

Porto Alegre - RS - Brasil

CEP $90035-190$

Telefone: +55 (51) 3308-4084

Fax: +55 (51) 3308-4054

www. seer. ufrgs. br/ ambienteconstruido

E-mail: ambienteconstruido@ufrgs.br 